Endocrinol. Jaron. 1989, 36 (3), 343-349

\title{
Malignant Lymphoma of the Thyroid and Epstein-Barr Virus
}

\author{
Sunao MATSUbAYASHI ${ }^{1}$, Hajime TAMAI $^{1}$, Tetsuya MORITA ${ }^{1}$, \\ KENJi MORI ${ }^{1}$, TAKATO KATSUKI ${ }^{2}$, FUMIo MATSUZUKA ${ }^{3}$, \\ KANJI KUMA ${ }^{3}$ AND SHIgENOBU NAGATAKI ${ }^{4}$ \\ ${ }^{1}$ Department of Psychosomatic Medicine, \\ Faculty of Medicine, Kyushu University, Fukuoka; \\ ${ }^{2}$ The Department of Microbiology, \\ Kumamoto University School of Medicine, Kumamoto; \\ ${ }^{3}$ Kuma Hospital, Kobe ; \\ ${ }^{4}$ The Department of Internal Medicine \\ Nagasaki University School of Medicine, Nagasaki, Japan
}

\begin{abstract}
We have investigated the specific immune response to Epstein-Barr virus (EBV) of peripheral blood mononuclear cells (PBMC) from patients with malignant lymphoma of the thyroid. Coculture of PBMC and EBV resulted in EBV cell transformation and regression which was assayed by an EBVinduced B cell focus-regression assay technique. The EBV had been isolated from mouthwash samples. The specific immune response to EBV by outgrowth inhibition in PBMC from untreated EBV-seropositive patients with malignant lymphoma was significantly decreased when compared to PBMC from EBVseropositive healthy subjects $(p<0.05)$. This observation is at least consistent with the possibility that B-cell proliferation after continuous or recurrent EBV infection could be a causative factor or may potentiate malignant lymphoma of the thyroid.
\end{abstract}

Malignant lymphoma of the thyroid occurs at the rate of $5 \%$ among thyroid neoplasms (Stauton et al., 1973), and most prove to be cases of B-cell lymphoma (Maurer et al., 1979; Aozasa et al., 1986).

The ubiquitious Epstein-Barr virus (EBV), which can readily transform normal human B-cells in vitro to blast cells with infinite replicative ability, frequently leads to a self-

Received October 28, 1988

Correspondence: Dr. SUNAO MATSUBAYASHI: Department of Psychosomatic Medicine, Faculty of Medicine, Kyushu University, 3-1-1 Maidashi. Higashi-ku, Fukuoka 812, Japan limiting lymphoproliferative disease, e. g., infectious mononucleosis (Henle and Henle, 1981). The EBV may also be implicated in the etiology of some cases of Burkitt's lymphoma (Old et al., 1966) and nasopharyngeal carcinoma (Tamada et al., 1984). Polyclonal and monoclonal B-cell lymphomas induced by EBV have occurred after infectious mononucleosis (Abo et al., 1982) and renal transplantation (Hanto et al., 1983). Moreover, the EBV antibody titers in patients with malignant lymphoma exceed those observed in patients with Hashimoto's thyroiditis (Matsubayashi et al., 1987). Of course, 
whether this finding relates to pathogenetic factors or is secondary, is not clear.

In this study, we have analyzed the EBVspecific immune response in peripheral blood mononuclear cells (PBMC) from six patients with malignant lymphoma of the thyroid. The possible relationship of these findings to the etiology of malignant lymphoma of the thyroid is discussed below.

\section{Materials and Methods}

Blood samples and mouthwash samples were obtained from six patients with malignant lymphoma of the thyroid ( 2 men and 4 women; 47-68 years), who were all in stage 1 of the disease. Their EBV immune response was compared with data from seven healthy agematched controls ( 2 men, 5 women; 48-72 years) who were EBV-seropositive donors. The diagnosis of malignant lymphoma was based on findings in the biopsy specimens classified by the morphologic criteria of Kiel (Lennert, 1981): three were centroblastic/centrocytic, one was immunoblastic, one was centrocytic, and one was lymphoplasmacytic/lymphoplasmacytoid. The expression of immunoglobulin (Ig) light chains in the proliferating cells was restricted in all of the patients. In none of the six patients or seven controls were adult $\mathrm{T}$-cell leukemia virus associated antigens present in these sera; this was checked before the study. Sera and peripheral mononuclear cells (PBMC) were separated by the Ficoll technique. PBMC were resuspended in the medium (RPMI 1640 medium containing heated $10 \%$ fetal calf serum), adjusted to $1 \times 10^{6}$ cells $/ \mathrm{ml}$, and cultured at $37^{\circ} \mathrm{C}$ in a $\mathrm{CO}_{2}$ incubator $\left(\begin{array}{ll}5 \% & \left.\mathrm{CO}_{2}\right) \\ \end{array}\right.$ samples were obtained after the subjects gargled for 30 seconds with $150 \mathrm{ml}$ of RPMI 1640 medium.

\section{$E B V$ antibodies}

The titers of IgG to the vial capsid antigen of EBV (EBVCA) and early antigen IgG (EBVEA) and of antibodies to EBV-determined nuclear antigen (EBVNA) were assayed in all serum samples before performing the test of EBV-specific cytotoxic T-cell function (see below). Anti-EBVCA and EBVEA titers were assayed by indirect immunofluorescence, and anti-EBVNA titers by an anti-complement immunofluorescent method (Henle and Henle, 1978). Serial twofold dilutions starting at $1: 10$ were used to obtain the antibody titers. Titers of $1: 10$ or greater were considered to be positive for EBVCA, EBVEA, and EBVNA.

\section{$E B V$-specific immune response}

The EBV-specific immune response was investigated by using out growth inhibition (Moss et al., 1978 ; Rickinson et al., 1981 ; Moss et al., 1981), also, as published previously by one of us (Katsuki, 1987); briefly, EBV (B95-8) was obtained by the culture of EBV-producing cells $\left(3 \times 10^{5}\right.$ cells $\left./ \mathrm{ml}\right)$ with a viability of over $90 \%$ for $7-10$ days at $37^{\circ} \mathrm{C}$, the medium then being centrifuged at $2,000 \mathrm{rpm}$ for $10 \mathrm{~min}$. The supernatant was passed through a membrane filter with $0.45 \mu \mathrm{m}$ pores and kept at $-80^{\circ} \mathrm{C}$ before co-culture of PBMC. PBMC $\left(1.6 \times 10^{6}\right)$ were incubated with $0.3 \mathrm{ml}$ of $\mathrm{EBV}$ at $37^{\circ} \mathrm{C}$ (EBV adhesion to mononuclear cells). The cells were then washed twice in the medium. $2.5 \times$ $10^{4}$ cells, or cells concentrated twofold serially were seeded into six wells each in a 96-well culture dish and cultured at $37^{\circ} \mathrm{C}$ for 50 days. Each well contained $150 \mu 1$ of medium. Half of the medium was changed every 3-5 days. At the end of culture, the establishment of EBVtransformed cells or the regression of EBVtransformed cells in each well was investigated by microscopic observation; the appearance of progressively growing foci of transformed cells was detected in the establishment of EBVtransformed cells. The regression index (the initial cell concentration required to achieve $50 \%$ incidence of regression in EBV-infected cell cutures; $\mathrm{IR}_{50} / \mathrm{ml}$ ) was calculated by the method of Reed-Muench (Moss et al., 1978); $\sqrt{\mathrm{a} / 3} \times \mathrm{b}$ (a: number of wells showing transformation cells, $b$ : initial seeded PBMC concentrations divided $10^{4}$ ).

\section{Isolation of $\mathrm{EBV}$ from mouthwash samples}

Transforming EBV were assayed with umblical cord lymphocytes (Katsuki and Hinuma, 1975). Both $1 \times 10^{6}$ 1ymphocytes from umblical cord blood and $1.0 \mathrm{ml}$ mouthwash samples serially diluted tenfold, starting at $1: 10$, were incubated at $37^{\circ} \mathrm{C}$ for $1 \mathrm{hr}$. The virus first adhered to the lymphocytes; then the cells were washed and resuspended in medium and cultured at $37^{\circ} \mathrm{C}$ 
Table 1. Titers of antibodies to EBV- and ATLV-associated antigens in sera

\begin{tabular}{|c|c|c|c|c|c|}
\hline \multirow{2}{*}{ Donor } & \multirow{2}{*}{ Age/Sex } & \multicolumn{4}{|c|}{ IgG Antibody titer to } \\
\hline & & ATLA $^{1}$ & $\mathrm{VCA}^{2}$ & $\mathrm{EA}^{3}$ & EBNA $^{4}$ \\
\hline \multicolumn{6}{|c|}{ With malignant lymphoma of the thyroid } \\
\hline 1 & $47 / \mathrm{F}$ & $<10$ & 640 & 80 & 80 \\
\hline 2 & $68 / \mathrm{M}$ & $<10$ & 160 & $<10$ & 80 \\
\hline 3 & $66 / \mathrm{M}$ & $<10$ & 5120 & 160 & 640 \\
\hline 4 & $59 / \mathrm{F}$ & $<10$ & 640 & 1280 & 40 \\
\hline 5 & $57 / \mathrm{F}$ & $<10$ & 40 & $<10$ & 80 \\
\hline 6 & $54 / \mathrm{F}$ & $<10$ & 160 & $<10$ & 20 \\
\hline \multicolumn{6}{|c|}{ EBV-seropositive healthy controls } \\
\hline 1 & $63 / \mathrm{F}$ & $<10$ & 320 & $<10$ & 40 \\
\hline 2 & $48 / \mathrm{M}$ & $<10$ & 160 & $<10$ & 40 \\
\hline 3 & $58 / \mathrm{F}$ & $<10$ & 80 & $<10$ & 40 \\
\hline 4 & $72 / F$ & $<10$ & 320 & 20 & 160 \\
\hline 5 & $66 / F$ & $<10$ & 160 & $<10$ & 80 \\
\hline 6 & $56 / \mathrm{M}$ & $<10$ & 40 & $<10$ & 40 \\
\hline 7 & $70 / F$ & $<10$ & 160 & 20 & 80 \\
\hline
\end{tabular}

${ }^{1}$ Adult T-cell leukemia viral antigen. ${ }^{2}$ Viral capsid antigen. ${ }^{3}$ Early antigen (DR complex).

${ }^{4}$ EBV-determined nuclear antigen. Titers of EBV-antigen antibodies in the two groups were similar.

for 50 days. Half the medium was changed every 3-5 days. Transformed B-cell lines (EBVNA positive) detected by an anti-complement immunofluorescent method (Katsuki and Hinuma, 1975) were judged to be positive for EBV. There were 5 wells for each dilution.

\section{Statistical analysis}

Wilcoxon's rank-sum test was used for statistical analysis.

\section{Results}

\section{EBV antibodies}

The results of tests for antibodies to EBVCA, EBVEA, and EBVNA are shown in Table 1. All six patients and seven controls had EBVCA and EBVNA antibodies in the serum. The titers of anti-EBVCA, EBVEA, and EBVNA in two groups were similar.

\section{$E B V$-specific immune response}

The incidence of transformation in the well culture of PBMC infected by EBV is shown in Table 2 . The regression index (mean $\pm S D$ ) in the patients and in the controls was $35.4 \pm 26.9$ and $10.2 \pm 3.7$, respectively, the difference being significant $(\mathrm{p}<0.05)$.

\section{Isolation of EBV from mouthwash samples}

EBV-infected umblical B-cells (transformed B-cells) were observed in three of the six patients and in one of the seven controls $(\mathrm{p}<0.1$, not significant) (Table 3$)$.

\section{Discussion}

The association between malignant lymphoma of the thyroid and Hashimoto's thyroiditis may indicate a causal relationship in which chronic antigenic stimulation of lymphocytes causes their eventual transformation into lymphoma cells (Burke et al., 1977, Holm et al., 1985; Kato et al., 1985). However, the factors that transform the 
Table 2. Incidence of transformation in cultures of peripheral blood mononuclear cells infected with EBV (B95-8)

\begin{tabular}{|c|c|c|c|c|c|c|c|c|}
\hline \multirow{3}{*}{ Donor } & \multicolumn{6}{|c|}{$\begin{array}{l}\text { Number of culture well showing } \\
\text { transformation cell concentrations }\end{array}$} & \multirow{3}{*}{$\begin{array}{l}\text { Regression } \\
\text { index }^{1}\end{array}$} & \\
\hline & \multicolumn{6}{|c|}{$\times 10^{4} / \mathrm{ml}$ of peripheral mononuclear cells } & & \\
\hline & 80 & 40 & 20 & 10 & 5 & 2.5 & & \\
\hline \multicolumn{9}{|c|}{ With malignant lymphoma of the thyroid } \\
\hline 1 & $0 / 6$ & $0 / 6$ & $0 / 6$ & $4 / 6$ & $6 / 6$ & $5 / 6$ & 11.9 & \\
\hline 2 & $1 / 6$ & $4 / 6$ & $6 / 6$ & $6 / 6$ & $6 / 6$ & $6 / 6$ & 51.3 & \\
\hline 3 & $0 / 6$ & $2 / 6$ & $5 / 6$ & $6 / 6$ & $5 / 6$ & $3 / 6$ & 31.3 & $35.4 \pm 26.9^{*}$ \\
\hline 4 & $3 / 6$ & $4 / 6$ & $6 / 6$ & $6 / 6$ & $6 / 6$ & $6 / 6$ & 80.0 & \\
\hline 5 & $0 / 6$ & $0 / 6$ & $0 / 6$ & $1 / 6$ & $5 / 6$ & $6 / 6$ & 7.1 & \\
\hline 6 & $0 / 6$ & $2 / 6$ & $5 / 6$ & $6 / 6$ & $6 / 6$ & $6 / 6$ & 31.3 & \\
\hline \multicolumn{9}{|c|}{ EBV-seropositive healthy controls } \\
\hline 1 & $0 / 6$ & $0 / 6$ & $0 / 6$ & $6 / 6$ & $6 / 6$ & $6 / 6$ & 14.1 & \\
\hline 2 & $0 / 6$ & $0 / 6$ & $0 / 6$ & $0 / 6$ & $5 / 6$ & $6 / 6$ & 6.6 & \\
\hline 3 & $0 / 6$ & $0 / 6$ & $0 / 6$ & $1_{i}^{\prime} 6$ & $6 / 6$ & $6 / 6$ & 7.6 & $10.2 \pm 3.7$ \\
\hline 4 & $0 / 6$ & $0 / 6$ & $0 / 6$ & $4 / 6$ & $6 / 6$ & $6 / 6$ & 11.9 & \\
\hline 5 & $0 / 6$ & $0 / 6$ & $0 / 6$ & $0 / 6$ & $3 / 6$ & $6 / 6$ & 5.0 & \\
\hline 6 & $0 / 6$ & $0 / 6$ & $1 / 6$ & $4 / 6$ & $6 / 6$ & $6 / 6$ & 12.8 & \\
\hline 7 & $0 / 6$ & $0 / 6$ & $0 / 6$ & $5 / 6$ & $6 / 6$ & $6 / 6$ & 13.2 & \\
\hline
\end{tabular}

${ }^{1}$ Initial cell concentration required to achieve $50 \%$ incidence of regression in EBV-infected cell cultures.

$* \mathrm{p}<0.05$ vs. regression index in controls. Results are expressed as means \pm SD.

Table 3. Isolation of EBV from mouthwash samples

\begin{tabular}{|c|c|c|c|}
\hline & Dilution & of mouthwash & samples \\
\hline Donor & 1 & $10^{-1} \quad 10^{-2}$ & $10^{-3}$ \\
\hline
\end{tabular}

With malignant lymphoma of the thyroid

$\begin{array}{lllll}1 & 5 / 5 & 5 / 5 & 2 / 5 & 0 / 5 \\ 2 & 4 / 5 & 1 / 5 & 0 / 5 & 0 / 5 \\ 3 & 0 / 5 & 0 / 5 & 0 / 5 & 0 / 5 \\ 4 & 5 / 5 & 2 / 5 & 0 / 5 & 0 / 5 \\ 5 & 0 / 5 & 0 / 5 & 0 / 5 & 0 / 5 \\ 6 & 0 / 5 & 0 / 5 & 0 / 5 & 0 / 5\end{array}$

EBV-seropositive healthy controls

$\begin{array}{lllll}1 & 0 / 5 & 0 / 5 & 0 / 5 & 0 / 5 \\ 2 & 0 / 5 & 0 / 5 & 0 / 5 & 0 / 5 \\ 3 & 5 / 5 & 1 / 5 & 0 / 5 & 0 / 5 \\ 4 & 0 / 5 & 0 / 5 & 0 / 5 & 0 / 5 \\ 5 & 0 / 5 & 0 / 5 & 0 / 5 & 0 / 5 \\ 6 & 0 / 5 & 0 / 5 & 0 / 5 & 0 / 5 \\ 7 & 0 / 5 & 0 / 5 & 0 / 5 & 0 / 5\end{array}$

$\mathrm{p}<0.1$ for malignant 1ymphoma of the thyroid vs. EBV-seropositive healthy controls reactive intrathyroidal lymphocytes to lymphoma cells are unknown.

In susceptible persons, EBV infects Bcells, followed by extensive proliferation of suppressor/cytotoxic T-cells (De Waele et al., 1981); such cells help control the transformation of infected B-cells (Rickinson et al., 1981). Abo et al. (1982) have suggested that monoclonal malignant lymphoma arises after infectious mononucleosis as a result of EBV infection. It is well-known that clonal B-cell expression and malignant lymphomas consisting of EBV-infected cells occur in immunosuppressed patients (Penn, 1986). On the other hand, EBV infection has been thought to be a causative factor in a subtype of both malignant nonHodgkin's lymphoma (Wultzler et al., 1986) and Hodgkin's lymphoma (Weiss et al., 1987, Staal et al., 1989) as suggested by Southern blotting analysis of EBV-DNA. By analogy, therefore, it may be considered that EBV 
could be a possible causative factor in malignant lymphoma even in the absence of an immunoinsufficient state. Patients with malignant lymphoma of the thyroid have higher titers of EBVNA antibodies than patients with Hashimoto's thyroiditis (Matsubayashi et al., 1987), whereas patients with Hashimoto's thyroiditis frequently have higher titers of EBVNA than normal persons (Matsubayashi et al., 1987). These findigs have suggested that EBV may be important in the development of malignant lymphoma of the thyroid, either as a pathogenetic factor or as a consequence of the disease. In this study, we found a significant decrease in the EBV-specific immune response due to outgrowth inhibition (i. e., a long-term $\mathrm{T}$-cell mediated immune reaction of PBMC to EBV measured by an EBV-induced B-cell focus-regression assay), as well as a slight tendency for EBV to be found more frequently in mouthwash samples in patients with malignant lymphoma of the thyroid than in EBV-seropositive healthy subjects. It is not yet evident whether these observations relate to the cause of the malignant lymphoma of the thyroid or are a consequence of it. If the former, it is possible that the impaired suppressor/cytotoxic $\mathrm{T}$-cell response to EBV in the PBMC from patients with malignant lymphoma of the thyroid may allow EBV to readily proliferate. Conversely, if these effects are a consequence of the disease, then the decrease in EBV specific suppressor/ cytotoxic function may reflect a vicious circle resulting in proliferation of B-cells in this disease. EBV is a common virus and could be present in lymphoreticular tissue (such as lymph nodes, tonsils and Hashimoto's thyroiditis), through the oral cavity and might transform B-cells in the neck region. To suggest a direct role of EBV infection in the development of malignant lymphoma of the thyroid, it would be necessary to find proviral DNA in the nuclei of the tumor cells of such lymphomas.

\section{Acknowledgement}

The authors are most grateful to Professor Robert Volpé for reading the manuscript.

\section{References}

Abo, W., K. Takada, M. Kamada, M. Imamura, T. Motoya, M. Iwanaga, T. Aya, S. Yano, T. Nakao and T. Osato (1982). Evolution of infectious mononucleosis into Epstein-Barr virus carrying monoclonal malignant lymphoma. Lancet 1, 1272-1276.

Aozasa, K., A. Inoue, K. Tajima, A. Miyauchi, F. Matsuzaka and K. Kuma (1986). Malignant lymphoma of the thyroid gland. Analysis of 79 patients with emphasis on histologic prognostic factors. Cancer 58, 100-104.

Burke, J, J. J. Butler and L. M. Fuller (1977). Malignant lymphoma of the thyroid, a clinical pathologic study of 35 patients including ultrastructual observations. Cancer $89,1587-1602$.

De Waele, M., C. Thielemans and B. K. G. Van, Camp (1981). Characterization of immunoregulatory T-cells in EBV-induced infectious mononucleosis by monoclonl antibodies. N. Engl. J. Med. 304, 460-462.

Hanto, D. W., K. J. Gaji-Peczalska, G. Frizzera, D. C. Arthur, H. H. Balfour Jr. K. McClain, R. L. Simmons and J. S. Najarian (1983). Epstein-Barr virus (EBV) induced polyclonal and monoclonal B-cell lymphoproloferative disease occurring after renal transplantation. Ann. Surg. 198, 356-369.

Henle, W. and G. Henle (1978). The immunological approach to study of possibly virusinduced human malignancies using the EpsteinBarr virus as example. Prog. Exp. Tumor. Res. 21, 19-48.

Henle, W. and G. Henle (1981). Epstein-Barr virus-specific serology in immunologically compromised individuals. Cancer Res. 41, 4222-4225.

Holm, L. M., H. Blomgren and T. Lowhagen (1985). Cancer risks in patients with chronic lymphocytic thyroiditis. N. Engl. J. Med. 312, 601-604.

Kato, I., K. Tajima, T. Suchi, K. Aozasa, F. 
Matsuzuka and K. Kuma (1985). Chronic thyroiditis as a risk factor of B-cell lymphoma in the thyroid gland. Jpn. J.Cancer. Res. 76, $1085-1090$.

Katsuki, T. (1987). Assay of long-term T-cell mediated immunity of Epstein-Barr virus in EBV-seropositive donors. Clin. Immunol. 19 (Suppl. 12), 267-270 (in Japanese).

Katsuki, T. and Y. Hinuma (1975). Chracteristics of cell lines derived from human leukocytes transformed by different strains of EpsteinBarr virus. Int. J. Cancer 15, 203-210.

Lennert, K. (1981). Histopatology of nonHodgkin's lymphomas (based on the Kiel classification), Springer-Verlag, Berlin, Heidel berg, New York.

Matsubayashi, S., H. Tamai, K. Nagai, K. Mori, F. Matsuzuka, T. Katsuki, S. Nagataki and K. Kuma (1987). The immunopathogenesis of malignant lymphoma of the thyroid. In: Recent progress in thyroidology (A Vichayanrat, W. Nitiyanant, C. Eastmann, S. Nagataki eds.), Crystal House Press, Bangkok. pp 198-200.

Maurer, R., C. R. Taylor, R. Terry and R. J. Lukes (1979). Non-Hodgkin's lymphomas of the thyroid. Virchows Archiv. A (Path. Anat. and Histol.) 383. 293-317.

Moss, D. J., A. B. Rickinson and J. H. Pope (1978). Long-term T cell-mediated immunity to Epstein-Barr virus in man. I. Complete regression of virus-induced transformation in cultures of seropositive donor leukocytes. Int. J. Cancer 22, 662-668.

Moss, D. J., L. E. Wallace, A. B. Rickinson and A. Epstein (1981). Cytotoxic T cell recognition of Epstein-Barr virus-infected Bcells. 1. Specificity and HLA restriction of effector cells reactivated in vitro. Eur. J. Im- munol. 11, 686-693.

Old, B. L. J., E. A. Boyse, E. De Harven, H. G. Geering, B., Williamson and P. Glifford (1966). Precipitating antibody in human serum to an antigen present in cultured Burkittt's lymphoma cells. Proc. Natl. Acad. Sci. USA 56, 1699-1704.

Penn, I. (1986). Cancer is a complication of severe immunosuppression. Surg. Gynecol. Obstet. 162, 603-610.

Rickinson, A. B., D. J. Moss, L. E. Wallace, M. Rowo, I. S. Misko, M. A. Epstein and J. H. Rope (1981). Long-term T-cell mediated immunity to Epstein-Barr virus. Cancer Res. 41, 4216-4221.

Staal, S. P., R. Ambinder, W. E. Beschorner, G. S. Hayward and R. Mann (1899). A survey of Epstein-Barr virus DNA in lymphoid tissue. Frequent detection in Hodgkin's. disease. Am. J. Clin. Pathol. 91, 1-5.

Stauton, H. D. and W. P. Greening (1973). Clinical diagnosis of thyroid cancer. Br. Med. J. 4, 532-535.

Tamada, A., K. Makimoto, H. Yamabe, J. Imai, Y. Hinuma, A. Oyagi and T. Arai (1984). Titers of Epstein-Barr virus-related antibodies in nasopharyngeal carcinoma in Japan. Cancer 53, 430-440.

Weiss, L. M., J. G. Strickler, R. A. Warnke, D. T. Purtilo and J. Sklar (1987). EpsteinBarr viral DNA in tissue of Hodgkin's disease. Am. J. Pathol. 129, 86-91.

Wulzler, P., I. Färber, A. Sauerbrei, B. Helbig, K. Wutke, K-D. Rüdiger, K. Scheibner, B. Břichàček and V. Vonka (1986). Demonstration of Epstein-Barr virus in malignant nonHodgkin's 1ymphomas. Oncology 43, 224229. 